\title{
A composite index of formal sovereignty for small islands and coastal territories
}

\author{
François Alberti \\ Université Clermont Auvergne, CNRS, IRD, CERDI, France \\ francois.alberti@etu.uca.fr
}

\section{Michaël Goujon}

Université Clermont Auvergne, CNRS, IRD, CERDI, France michael.goujon@uca.fr (corresponding author)

\begin{abstract}
We build a composite index of formal sovereignty as an alternative to the binary classification 'Sovereign vs Affiliated' for the purpose of a comparative, quantitative analysis on a large sample of small islands. This index takes into account different degrees of sovereignty through the different attributes of sovereignty (diplomacy, executive, legislative, judicial, defence, and monetary). We use a conservative method to code the components and to aggregate them, trying to stay as simple and objective as possible, while remaining transparent and laying the foundations for future improvements. The index is calculated for a sample of 104 small islands and coastal territories. The results show that the binary classification based on United Nations (UN) membership is significantly limited, if not mistaken, because according to our index some territories which are not UN members have a higher sovereignty score than some UN members.
\end{abstract}

Keywords: affiliation, coding, composite index, small islands, sovereignty

https://doi.org/10.24043/isj.96 • Received November 2018, accepted July 2019

(C) 2020-Institute of Island Studies, University of Prince Edward Island, Canada.

\section{Introduction}

Degree of sovereignty is still an important research topic in small island studies. Questions remain about the process of decolonization - for instance, why and how islands adopt sovereignty or an intermediary status between sovereignty and full affiliation. Political status has also been studied as a determinant of long-term development and the differences in the level of economic performance between small islands.

The starting point of our contribution is the limitations and the possible oversimplification of the use of a binary classification of islands into Sovereign territories (United Nations - UN members) and Affiliated (Non-sovereign) territories (not UN members). While this has been addressed and discussed at length in qualitative studies of small samples, it is still lacking in comparative, quantitative analyses on large samples. Since the number of small islands which can be studied is large, around 100, it is logical that small island 
studies are often confronted with this problem (recent examples of large sample studies using a binary classification can be found in Bertram, 2004, 2015; Dunn, 2011; Feyrer \& Sacerdote, 2009; McElroy \& Pearce, 2006; McElroy \& Sanborn, 2005).

The limitations can be explained by two problems: (i) formal sovereignty: based on formal (written or unwritten) institutions and rules, legal status cannot be divided into two distinct classes of 'Sovereign' or 'Affiliated' due to the existence of many intermediary forms; (ii) informal politics interferes with formal rules to form de facto sovereignty, which may differ a great deal from formal sovereignty (useful analyses on informal politics and de facto sovereignty can be found in Grydehøj, 2016a and Veenendaal, 2018). In this paper we focus only on the problem of formal sovereignty, because for a comparative study on a large sample of islands, it is necessary to resolve the first problem before moving on to the second.

Our contribution consists of proposing an alternative to the binary classification 'Sovereign vs Affiliated'. Our index is numerical, and allows comparison of the degree of formal sovereignty on a continuous scale, reflecting the sovereignty 'spectrum' for many small islands and coastal territories. We also take into account the multidimensionality of the concept of sovereignty, by embracing the different dimensions of power in governing a territory.

Our method consists of coding the different components of formal sovereignty to generate numerical scores and aggregating them into a composite index. While the general framework of this kind of exercise is well-established in social, economics, and political sciences (e.g., democracy or governance indices), to our knowledge there has not yet been an attempt for the concept of sovereignty and specifically not for small islands. A possible explanation is that the ambiguity and the complexity of political status mainly concerns small island territories, which are not a primary focus in mainstream comparative and quantitative analyses.

Scoring from coding institutions and rules is, among other examples, the basis of Hooghe et al's (2010) Regional Authority Index, Ladner et al's (2016) Local Autonomy Index, and Cukierman's (2009) index for the legal independence of central banks. We follow the general principles of the methodology of these works to build our index.

We use the usual definition of sovereignty and the specific literature on small island sovereignty to identify components and subcomponents of the composite index. We follow a conservative approach to score the subcomponents and to aggregate them. We try to stay as simple and objective as possible, while remaining transparent by giving details on specific cases. Our work is also driven by the availability of the qualitative information that must be used to generate comparative data for a large sample. This is why we privilege the use of publicly available and recognized international databases, which also allows replication and updating. The number of small islands and coastal territories covered by our index is 104 , including island territories, mainland territories that are SIDS members or observers, and, for the purposes of comparison, a number of mainland microstates and small coastal subnational jurisdictions with special territorial status. This work should not be considered as definitive, and should encourage participative work to make further progress: the current coding process could be revised by other scholars, particularly where there are conceptual ambiguities, and coverage could be extended to more territories.

The results show that the binary classification 'Sovereign vs Affiliated' based on UN membership is significantly limited, if not wrong, because according to our index some territories that are not UN members have a higher sovereignty score than some UN members. 
The rest of the paper is organized as follows: the first sections detail the motivations and the methodology, and the main elements of the composite index; the following sections give details on the components and subcomponents of the composite index; and the final sections are devoted to an overview of the results, discussion, and conclusion.

\section{Motivations}

Degree of sovereignty is still an important research topic in small island studies. Questions remain about the process of decolonization, such as why and how islands adopt sovereignty or an intermediary status between sovereignty and affiliation. Political status has also been studied as a key determinant of long-term development and differences in the level of economic performance between small islands.

The complexity of the concept of sovereignty in the study of small islands context is discussed in detail in Bonilla and Hantel (2016) (specifically in the Caribbean context). Watts (2009) also considers that sovereignty has a particular meaning for islands, because islandness, remoteness, and uniqueness generate pressures for autonomy which can be sustained and balanced by the advantages of collaboration. Sovereignty is linked to questions of secessionism and federalism (see a recent review in Madiès et al, 2018). Small islands which are part of a larger country, but are both geographically and culturally distant from the rest of the country, may display more secessionist tendencies. This may push central government to grant some degree of autonomy to these territories without complete loss of decision-making power. However, empirical analyses on secessionism usually focus on mainland subnational jurisdictions and cover the specific cases of small islands to a lesser extent. Full and partial sovereignty or autonomy can also be discussed in a more general setting of non-self-governing territories which include islands and territories which are part of a mainland (Gagnon and Keating, 2012). Suksi (2012) analyses the conceptual distinction between federalism (involving a symmetrical transfer of law-making power and shared power at the federal level) and autonomy (an asymmetrical transfer or of 'special' nature). Rezvani (2014) investigates sovereignty and various forms of political autonomy by analysing the case of the "partially independent territories' (PIT): a large, diverse, intermediate category between sovereignty and non-sovereignty. He defines PITs as territories not under the full authority of a central government nor a member-unit of a federation; a PIT is constitutionally unincorporated into a core state but divides or shares sovereign power (and is a nationalistically distinct entity). He also distinguishes de jure or legal authority through formal (written) or informal (unwritten) constitutional rules, and de facto authority defined as the actual ability to control. These streams of research provide the background to, and a general framework for, our contribution.

There are numerous works that precisely describe the complexity that characterizes the different forms and degrees of partial sovereignty of small islands. Baldacchino (2010, p.91) states that the choice of 'autonomies' are viable alternatives to sovereignty for small islands, and "should not, in most cases, be seen naively as a case 'in transit' toward full sovereignty." Baldacchino and Hepburn (2012, p.12) document and discuss numerous cases of "different kind(s) of sovereignty." Karlsson (2009) explores variations in the subnational island jurisdictions category with a comparative analysis of Åland, Faroes, and Greenland. Mrgudovic (2012, p.456) explores the French territories in the south Pacific which "have experienced specific and customised statuses with various degrees of autonomy, all 
underscoring a fine line between autonomy and sovereignty." Overton et al (2012, p.237) argue that in Oceania "sovereignty is not a simple issue," and consider a wide range of status between sovereignty and affiliation. Prinsen et al (2017, p.1) note that every non-selfgoverning island has developed "its own arrangement of sovereignty attributes" rather than acquiring full Westphalian sovereignty. Grydehøj (2016b, p.106) in his study of Greenland considers that the binary contradiction between independence and dependence is "oversimplified," and that islands must be located on a "spectrum of independence." Pöllath (2018, p.239) studied the different degrees of sovereignty of Pacific islands under USA control and he also considers that "the boundaries between autonomy and sovereignty are fluid." These authors discuss the concepts of partial sovereignty or autonomy, and detail the different characteristics of sovereignty for small islands, which we use below. They also discuss the mix between formal sovereignty and informal politics that generate complex forms of de facto sovereignty (see Grydehøj, 2016a; Veenendaal, 2018).

Some works have produced more refined classifications of status for a large number of territories. Watts (2009) demonstrates the diversity of the different constitutional statuses of island jurisdictions observed in the world as follows: individual (small and large) island states, sets of island (unions or federations), or portions of islands that are members of the UN (and Taiwan, which is considered as sovereign while not being a UN member); islands or groups of islands that are states or provinces of territories belonging to federations; and islands or groups of islands which have other autonomy arrangements with larger states (federacy, associated, confederal, and other arrangements). Rezvani (2014) covers islands and non-island territories, and also provides different categories of association with core states, and distinguishes between formal (legal-ruled), conventional (non-legal-ruled), and politicalformal basis. The University of Prince Edward Island's database of 114 Sub-National Island Jurisdictions around the world shows the variety of their political systems and autonomies (Stuart, 2008). However, while refining the classification, these works remain qualitative and do not offer the simple measure of the different degrees of sovereignty which would allow a direct comparison of the different statuses.

While qualitative studies of a limited number of cases can reveal, analyse, and compare the different degrees of small island sovereignty, previous comparative quantitative analyses on large samples have still come up short. Such studies typically use a simple binary classification of islands, Sovereign vs Affiliated, in regressions to test the impact of sovereignty on performance. For instance, in studying the comparative economic performance of small islands, McElroy and Sanborn (2005) use a sample of 19 'independent' islands and 16 'dependent' islands; and McElroy and Pearce (2006) and McElroy and Parry (2012) use a sample of 30 'independent' islands and 25 'non-sovereign' islands (the so-called 'subnational island jurisdictions'). Bertram (2015) categorizes 72 islands into 'sovereign independence' and 'affiliation with a metropolitan patron state' covering various statuses such as "integration, free association, commonwealth and territory status." Verstraeten et al (2016, p. 88) focus on the Caribbean and use UN and national information to distinguish between 'sovereign' and 'nonsovereign' states, defining sovereignty as "sovereign states - loosely defined as populations in defined territories that are represented by one government and have full control of their (inter)national affairs by international law - that gained political independence." Dunn (2011), as well as 'independent' and 'integrated with a patron country', has an intermediate 
category called 'associated with a patron country', following Bertram (2004), but only five islands are classified as 'associated' out of a sample of 41 islands in her study. A binary classification is also used in regressions by Armstrong and Read (2000) on a large sample of small island or mainland territories and microstates, and by Rezvani (2014) for a large sample of 'sovereign' states and 'partially independent' territories. Feyrer and Sacerdote (2009) use a binary classification of 'decolonized' vs 'colonized'.

These studies use a so-called 'dummy variable' in regressions, a binary variable that equals 1 for sovereign and 0 for affiliated or associated, and usually find a negative impact of this variable on development performance. This simple binary classification of the political status is usually based on United Nations (UN) definitions (or simply 'being a UN member' or 'having a seat at the UN' vs not). Another usual source is the CIA World Factbook which classifies countries and territories as 'Independent state', defined as people politically organized into a sovereign state with a definite territory; or 'Dependencies' or 'Areas of special sovereignty' as broad categories of political entities that are associated in some way with an independent state.

The limitations of the binary classification can be explained by two problems: (i) formal institutions and rules and the de jure status cannot be segmented into two distinct classes of 'Sovereign' or 'Affiliated' entities, given the existence of various degrees of intermediate statuses, and given the multiple attributes of sovereignty (which cannot be restricted to 'having a seat at the UN'); and (ii) informal politics interfere with formal rules to form de facto sovereignty which can differ from legal sovereignty. From the perspective of comparative studies on a large sample of islands, it is necessary to first resolve the problem of sovereign vs affiliated, which would then allow the disentanglement of de jure and de facto sovereignty in a second step. This is why in this paper we focus on formal sovereignty. The results of our index show that the binary classification is limited, if not mistaken.

\section{Methodology}

Our contribution consists of proposing an alternative to the binary classification 'Sovereign vs Affiliated' in the form of a numerical index that allows comparison of the degree of formal sovereignty of a large sample of small islands on a continuous scale, reflecting the so-called 'spectrum' of sovereignty. We also take into account the multidimensionality of the concept of sovereignty, embracing the different dimensions of power in governing a territory.

Our method consists of coding the different components of formal sovereignty to generate numerical scores and aggregating them in a composite index. Scoring formal sovereignty consists of coding formal institutions and rules, and not using experts' scores which are the usual basis of de facto governance indicators (e.g., Systemic Peace Polity IV Project's polity score on democracy, the World Bank Institute's Worldwide governance indicators). Arguably, coding for legal sovereignty can be done more easily than for de facto sovereignty, which is more subjective. Among other examples, coding formal institutions and rules is the basis of Hooghe et al's (2010) Regional Authority Index, Ladner et al's (2016) Local Autonomy Index for subnational administrations, and Cukierman's (2009) index of the legal independence of central banks. Our general principles are borrowed from these works. Hooghe et al's (2010) index is a composite index which aims to encompass the centralization vs decentralization or federal vs non-federal dichotomy and binary categorizations of measures of government structure. Their index measures the formal authority of 89 intermediate or 
regional governments in 42 countries on eight dimensions using a coding system (each dimension giving scores which are aggregated). Hooghe et al $(2010,2016)$ present in detail their methodology and explain that making the coding explicit allows replication, amendment, and/or refutation. Ladner et al $(2015,2016)$ developed an index for measuring and comparing local autonomy in 39 European countries partially following the work of Hooghe et al (2010). They used a network of experts to assess the autonomy of local governments of their respective countries on the basis of a common code book covering 11 subcomponents of various aspects of local autonomy.

The Financial Secrecy Index (FSI) is another interesting example of a quantitative composite index based on qualitative information (see the methodology for the FSI in Cobham et al, 2015). While it is a field which seems a long way from our subject, financial secrecy is related to a specific characteristic of a number of islands (and is related to the question of political status - see the discussion in Rezvani, 2014, Chapter 1). The aim of the FSI is also to improve on the simple binary classification, 'Tax-haven' or 'Not-tax-haven', by providing a continuous score for financial secrecy applied to a large number of jurisdictions. The secrecy score is a composite index based on a set of explicit, detailed, verifiable indicators which measure the secrecy provided to non-residents by the laws and regulations of jurisdictions (the number of indicators has increased over time to 20 in the 2018 version). The main and preferred data sources are official and public reports from international institutions and specialist tax databases and websites (and these data sources are complemented by a survey).

Coding formal institutions and rules, which is qualitative information, by their degree of sovereignty or independence, to generate numbers, requires subjective judgment. However, subjectivity can be minimized when coding only a few well-defined legal characteristics and using information only from formal constitutions, laws, and regulations. Additional information on how the regulations are applied is deliberately left out, since it defines de facto sovereignty. These principles make it possible to rank territories by their degree of formal sovereignty by various power dimensions with relatively few subjective judgments. In building our composite index, we have followed a conservative method to score the components and to aggregate them. We have tried to stay as simple and objective as possible and to refine the index, progressively. However, since coding needs continuous reliability checks, we explain the coding rules we use in detail below, to allow further discussion on possible discrepancies, re-evaluation, and agreement about criteria and scores. We also give details on specific cases.

Our work is also driven by the availability of the qualitative information which must be used to generate comparative data for a large sample of islands, thus justifying the use of international databases. Our main source of information is the CIA World Factbook, a recognized source of synthetic, homogenous information on various political dimensions which covers a large number of sovereign and non-sovereign islands, and is continuously updated. Other candidate databases were explored, but appeared to be less relevant to constitute the basis of our work for a number of reasons. For instance, the University of Prince Edward Island's database on 114 subnational island jurisdictions shows the variety of their political systems and autonomies (Stuart, 2008), but the information on sovereignty is less completely and homogeneously presented and outdated. A number of islands are not covered by the CIA World Factbook. In comparison to the list of island jurisdictions from Watts (2009) and to the list of subnational island jurisdictions from Stuart (2008), the CIA World Factbook does not entirely cover island jurisdictions that are states, provinces, or territories of large, mainland federations (e.g., Prince 
Edward Island, Newfoundland and Labrador in Canada, and Hawai'i in the US); other island territories having formal (but non-constitutional) or otherwise informal 'special' or asymmetrical arrangements with central powers (such as Kish Island in Iran; Jeju Island Autonomous Province in South Korea); indigenous island-based communities with some sovereignty within another state (such as Haida Gwaii/Queen Charlotte Islands in Canada; Aleutian Islands in the US; and the Torres Strait Islands in Australia); or de facto island powers in open confrontation or contestation with a central state (such as the Turkish Republic of Northern Cyprus, Tamil Eelam in Sri Lanka, and Southern Mindanao in the Philippines). With a few exceptions detailed in the next sections, these islands were not included in the current version of the database, but could be in the future versions.

A total of 104 small islands and coastal territories are covered by our index, including island territories, mainland territories that are Small Island Developing States (SIDS) members or observers, and for the purposes of comparison a number of mainland microstates and small subnational jurisdictions with special territorial status. The largest are Greenland, Nunavut in Canada (which consists of part of a coastal mainland and a vast archipelago), Papua New Guinea, and Cuba. The small coastal territories included are Guyana, Suriname, and GuineaBissau which are SIDS members, but also Gibraltar and Monaco-two very small coastal territories with special status. We also include French Guyana, a small, coastal French overseas territory situated between Guyana and Suriname. These small coastal territories share a number of characteristics with islands and so they are usually covered by comparative studies on small islands and/or on sovereignty (and some of them are members of the Alliance of Small Island States - AOSIS). This study is large, but should not be considered as definitive, and should encourage participative work to progress further. The current coding process could be subject to revision by other scholars, particularly where there are conceptual ambiguities, or where coverage could be expanded to more territories.

\section{An overview of the index}

Shaw (2017, p.157) recalled two useful definitions to identify criteria of political independence. Firstly, he quotes Article 1 of the 1933 Montevideo Convention on Rights and Duties of States that gave "the most widely accepted formulation of the criteria of statehood in international law". Hence, a state "as an international person" should fill different criteria: "(a) a permanent population; (b) a defined territory; (c) a government; (d) a capacity to enter into relations with other states". Shaw also quotes the 1991 Arbitration Commission of the European Conference on Yugoslavia which decided that a state "characterized by sovereignty" is defined as "a community which consists of a territory and a population subject to an organized political authority". These definitions lead to the consideration of a broad range of characteristics of a sovereign state that can be applied to small islands - given that the conditions for a "permanent population" and a "defined territory" are fulfilled. This definition, complemented by specific elements from the literature on small islands detailed below, allows the selection of a set of six dimensions of sovereignty to characterize an organized political authority: diplomacy, executive, legislative, judicial, defence, and monetary.

The general principle is to code the six dimensions to generate normalized scores (between 0 and 1), and to aggregate them. Except for one subcomponent (defence), we make use of more than one criterion leading to the generation of intermediate scores (0.5). The 
aggregation, by the use of a simple average (i.e., the same weight given to every dimension, with the hypothesis of the substitutability of the dimensions), generates scores between 0 and 1 for the composite index.

Table 1: Overview of the index.

\begin{tabular}{|c|c|}
\hline Dimensions & Criteria \\
\hline Diplomacy & $\begin{array}{l}2 \text { criteria: } \\
\text { UN member } \\
\text { UN agencies or AOSIS member } \\
\text { Score } 0 \text { or } 0.5 \text { or } 1\end{array}$ \\
\hline Executive power & $\begin{array}{l}3 \text { criteria: } \\
\text { Chief of State appointed locally } \\
\text { Government Head appointed locally } \\
\text { Full executive power } \\
\text { Score } 0 \text { or } 0.5 \text { or } 1\end{array}$ \\
\hline Judicial power & $\begin{array}{l}2 \text { criteria: } \\
\text { Own judiciary system } \\
\text { Judges appointed locally } \\
\text { Score } 0 \text { or } 0.5 \text { or } 1\end{array}$ \\
\hline Legislative power & $\begin{array}{l}2 \text { criteria: } \\
\text { Own Constitution with no external intervention } \\
\text { No subordination to external constitution } \\
\text { Score } 0 \text { or } 0.5 \text { or } 1\end{array}$ \\
\hline Defence & $\begin{array}{l}1 \text { criterion: } \\
\text { Own Military force } \\
\text { Score } 0 \text { or } 1\end{array}$ \\
\hline Monetary & $\begin{array}{l}2 \text { criteria: } \\
\text { Own currency } \\
\text { No hard peg to a foreign currency } \\
\text { Score } 0 \text { or } 0.5 \text { or } 1\end{array}$ \\
\hline $\begin{array}{l}\text { Composite index of } \\
\text { formal sovereignty }\end{array}$ & $\begin{array}{l}\text { The score of the composite is the simple average of the scores of } \\
\text { the } 6 \text { dimensions } \\
\text { Score between } 0 \text { and } 1\end{array}$ \\
\hline
\end{tabular}

\section{Component 1: Diplomacy}

The extent of diplomatic networks, or the "capacity to enter into relations with other states" is seen by Shaw (2017, p.160) as an "aspect of the existence of the entity in question as well as an indication of the importance attached to recognition by other countries." Shaw (2017, p.160) also puts forward the idea that it is "essential for a sovereign state to be able to create such legal relations with other units as it sees fit." and that a country which is not able to create such relations cannot be an independent state. Being part of the UN is seen as the ultimate recognition of the sovereignty of a state by the international community. The Charter of the UN stipulates that membership "is open to all peace-loving States that accept 
the obligations contained in the UN Charter and, in the judgment of the Organization, are able to carry out these obligations" (Chapter 2, article 4). In the literature, UN membership is considered as the prima facie evidence of such a diplomatic capacity, and is used to generate the usual binary variable of Sovereign vs Affiliated islands.

However, even though some islands are not members of the UN (Taiwan is a specific case), they may still be members of other international organizations, such as specialised agencies of the UN, as a means to expand their diplomatic relations abroad. As highlighted by Prinsen et al (2017, p.5), "a diplomatic representation in one or more of the UN's specialised organs without being a member of the UN is arguably the last step before acquiring full Westphalian sovereignty." There are many striking examples of this phenomenon: the Faroe Islands and Tokelau are members of the FAO without being members of the UN, and UNESCO has nine associate members which are not members of the UN, of which eight are islands (Prinsen et al, 2017). In this paper, we use information on membership of the eighteen UN specialised agencies (UN, n.d.).

The Alliance of Small Island States (AOSIS) is an international organisation which does not belong to the UN but which focuses on small island issues (AOSIS, 2019). AOSIS membership is an evidence of the will of some small islands to develop their own diplomatic networks. AOSIS defines itself as "a coalition of small islands and low-lying coastal countries" which aims to provide a "negotiating voice for small island developing States within the United Nations system" (AOSIS, 2019), focusing on environmental issues. AOSIS has 44 member states and observers. The Netherlands Antilles still appears on the member list of AOSIS as an observer, but this ex-constituent country of The Netherlands was dissolved in 2010, which resulted in five islands-Bonaire, Curaçao, Saba, Sint Eustatius, and Sint Maarten - which we take to be AOSIS members. Five members of AOSIS are not members of the UN nor of one of the UN agencies, reflecting the will of these 'dependent' islands to raise their profile as well as to develop their own foreign relations.

We use two different criteria for the diplomacy dimension: (1) UN membership; (2) membership of UN specialised agencies and/or membership of the AOSIS. Coding is as follows:

- If the small island is a member of the UN, a score of 1 is assigned.

- If not a member of the UN, but if the island is a member of at least one of the UN specialized agencies and/or is a member of the AOSIS, a score of 0.5 is assigned.

- If none of the above, a score of 0 is assigned.

According to this coding, the number of territories that are scored 1 is $43,0.5$ is 41 , and 0 is 20 .

\section{Component 2: Executive power}

According to the definition of a sovereign state given by the Arbitration Commission of the European Conference on Yugoslavia, and quoted by Shaw (2017, p.157), a sovereign state must be subject to "an organised political authority," using a system of executive power. Assessing independence in terms of executive power requires an understanding of who is in charge of carrying out the laws and of appointing officials. When the executive branch is headed by the chief of state, the degree of independence must primarily rely on the question of its origin. If we refer to the definition given by the CIA World Factbook, the chief of state is considered as the "titular leader of the country who represents the state at official and 
ceremonial functions but may not be involved with the day-to-day activities of the government" (CIA, 2019). If some small islands have their own chief of state, others still share their chief of state with a mainland country. However, in a number of cases, the chief of state can be a monarch with no real executive power. For instance, in a number of British Overseas Territories, the Queen, represented by a governor, appoints the premier or the prime minister following local elections, and executive power is fully or almost-fully exercised by the local prime minister. Most of the information on executive power is taken from the CIA World Factbook and completed by specific sources for some territories.

The executive power index uses three nested criteria to generate three different scores.

- The score is 1 when the chief of state and the head of the executive are appointed locally; or when the chief of state is not appointed locally but has no significant executive power and the head of the executive is appointed locally with full or almostfull executive power.

- The score is 0.5 when the chief of state is not appointed locally and when the head of the executive is appointed locally with partial executive power. This score is given to the overseas territories of France (e.g., New Caledonia), the Portuguese autonomous region (Azores and Madeira), the Spanish autonomous community of the Canary Islands, and also Pitcairn islands, where power is shared by the Governor and the mayor, etc.

- The score is 0 for the cases when the head of the executive is appointed externally or appointed locally but with no significant executive power. This is the case for the overseas departements of France (e.g., Martinique, where the head of the executive has not significantly more power than in the other regions or department of the mainland), and some British Crown territories where the executive is headed by an administrator (e.g., Akrotiri, BIOT), Bonaire, Saba, and Sint Eustatius which are special municipalities of the Netherlands, and the Norway Crown territory of Svalbard.

According to this coding, the number of territories that are scored 1 is $71,0.5$ is 16 , and 0 is 17 .

\section{Component 3: Judicial power}

Making the law and maintaining the order are two basic state functions and rely on both judicial and legislative powers. In component 3, we focus on the level of judicial sovereignty, based on two joint criteria. The first criterion is whether the judiciary is controlled by the territory or controlled by the mainland country, or shared. In a number of territories, while the judicial system is controlled by the territory, final appeals are heard by the supreme court of the mainland country. The second criterion is about the process in which judges are selected and appointed, whether it is fully or partially local, or by the choice of the mainland. This process can be indicative of the independence or of the subordination of an island's judicial system vis-à-vis the core country.

The coding assigns the score of 1 if the small island has its own judicial system and if there is no sign of any intervention from the mainland. An intermediary score of 0.5 is assigned when final appeals are heard by the core country supreme court or when the core country has a significant involvement in the designation and appointment of judges. A score of 0 is assigned to the cases where the judicial power is controlled by, or fully incorporated 
into the system of, the mainland. Most of the information is from the CIA World Factbook and has been completed by specific sources.

Some specific cases deserve discussion. For instance, the Eastern Caribbean Supreme Court (ECSC) is a superior court for the Organisation of Eastern Caribbean States (OECS). The members are six independent states: Antigua and Barbuda, the Commonwealth of Dominica, Grenada, Saint Kitts and Nevis, Saint Lucia, Saint Vincent and the Grenadines, and three British Overseas Territories: Anguilla, British Virgin Islands, and Montserrat. The chief justice of the ECSC, who always originates from a member country of the OECS, is appointed by the UK while other justices and judges are appointed by the Judicial and Legal Services Commission. It is the convention that the UK acts on the recommendation of the heads of government of the OECS member states (Van Zyl Smit, 2015). So, we consider that this judicial system shared by ECSC members does not show signs of significant subordination to an external power and a score of 1 is assigned to every member of the ECSC.

Another example of a shared system is the Joint Court of Justice of Aruba, Curaçao, Sint Maarten, and of Bonaire, Sint Eustatius and Saba. However, final appeals in these territories are heard by the Supreme Court in The Hague, Netherlands—so the coding is 0.5. According to this coding, 53 territories are scored 1, 15 are scored 0.5 , and 36 are scored 0.

\section{Component 4: Legislative power}

The legislative branch has the responsibility for making a nation's law. The constitution is "the body of doctrines and practices that form the fundamental organizing principle of a political state" (Encyclopaedia Britannica), and forms the basis of the legal system. Whether a small island has its own constitution, either in the form of written legal rules, or in the form of informal conventional rules, is essential for determining its degree of independence. The CIA World Factbook gives information about constitutions but also whether amendments are subject to the approval of the mainland.

Rezvani (2014) uses a constitutional basis to define 'partially independent territories' (PIT). PITs are not fully subordinate constitutionally to another power (through formal, conventional and political-formal forms of entrenchment that defend them from easy usurpation by the core state), but are constitutionally not incorporated with the core state (difference from federation); "PIT are also domestically unincorporated into the internal system of a core state in the sense that in significant respects they are not recognized 'as an integral part' of the rest of the country" (Rezvani, p. 26). Rezvani's list of PIT, which includes 34 small islands and coastal territories in our sample, is also used to identify intermediary statuses. Coding scoring is as follows:

- A score of 1: if the small island has its own constitution, with no sign of significant intervention from a mainland.

- A score of 0.5: if the constitution is subordinate to the one of a mainland country.

- A score of 0 : if the territory does not have its own constitution, if the constitution of a mainland country is applied, or if the constitution is fully subordinate to the mainland country constitution. 
For example, as shown in the CIA World Factbook, the French Constitution generally applies in New Caledonia, but specific changes were made following the Noumea Agreement of 1998. Moreover, New Caledonia appears in Rezvani's list of PITs. Hence, New Caledonia is scored 0.5. According to this coding, 45 territories are scored 1, 39 are scored 0.5 , and 20 are scored 0.

\section{Component 5: Defence}

One of the basic functions of a sovereign state is the defence of the national territory as well as internal and external security. In this way, having its own independent military forces would be a relevant attribute that should enter into our index of formal sovereignty. Arguably, de facto sovereignty could not depend a lot on the defence dimension and having its own military forces, specifically for small islands. One can consider that in our globalized world, national security does not depend greatly on military forces, and that the characteristic of smallness would anyway considerably reduce the importance of this characteristic. However, again, our aim is evaluate formal sovereignty.

In some cases, the territory is simply demilitarized. This is the case for Iceland or Mauritius which have a National Police and Coast Guard, but no regular military forces, while being internationally recognised and considered as sovereign states. In a number of cases, partial independence is explained by the role of furnishing military base rights (Rezvani, 2014), which translates into external defence being constitutionally surrendered to the core state. At the extreme, some territories have large parts of their surface covered by foreignowned military bases.

The coding is based on whether the small island possesses its own military forces. Most of the information is from the CIA World Factbook and is completed by specific sources of information for some territories. Territories which have their own regular military forces are scored 1 , and those that do not are scored 0 . According to this coding, 30 territories are scored 1 , and 74 are scored 0 .

\section{Component 6: Monetary sovereignty}

Monetary sovereignty is the exercise of legal control over the national currency, and is arguably one of the fundamental functions of a sovereign state. Zimmermann (2013) discusses the concept of monetary sovereignty and how it is subject to evolution in the context of globalization. The International Monetary Fund (IMF) defines three attributes of monetary sovereignty: the right to issue currency, the right to regulate the use of that currency, and the right to determine and change the value of the currency (Gianviti 2004). Logically the first criterion of monetary sovereignty should be having its own currency (and a national central bank that issues this currency). The IMF groups countries or territories which exclusively use a foreign currency (so-called 'dollarization'), into the 'no separate legal tender' category (out of the ten categories of exchange rate regimes defined by the IMF). The IMF classifies the exchange rate regime of the 189 IMF member countries. Most of them are sovereign states, but some of them are affiliated territories such as Hong Kong SAR, Aruba, Curaçao, and Sint Maarten (while this information can be gleaned from different sources, the IMF Annual Reports on Exchange Arrangements and Exchange Restrictions gives precise and updated classifications 
of de facto exchange rate regimes). On the other hand, the IMF does not classify Cuba and Taiwan which are usually considered as sovereign, and both of which have their own currency.

According to the current IMF classification, countries which are members of a monetary union are not classified in the 'no separate legal tender' category, signalling an ambiguity as to whether they surrender monetary sovereignty. For instance, all Eurozone members are classified in the 'free floating' category (the Euro floats freely against other international currencies), and the island members of the Organisation of Eastern Caribbean States are classified in the 'currency board' category (the East Caribbean dollar is hardly pegged to the USD). Arguably, monetary union is a form of joint exercise of monetary sovereignty or of cooperative sovereignty (Zimmermann, 2013). So, for the Eurozone, Cyprus and Malta being member of the Eurozone (having seats at the European Central Bank board) are not in the "no separate legal tender' category (this is also the case of Hawai'i which is a member of the Federal Reserve System). On the other hand, Kosovo, Montenegro, and San Marino which have adopted the Euro but are not member of the Eurozone (and do not have a seat on the ECB board) are in the 'no separate legal tender' category. We consider that this different classification is relevant given that our focus is on defining and measuring Sovereignty vs Affiliation of small territories vis-à-vis a mainland. Neither Cyprus nor Malta should be considered as falling into the affiliation category by becoming a full member of the Eurozone.

The affiliated islands and territories which are not classified by the IMF have various situations regarding monetary affairs. Some of them have their own currency (e.g., Aruba with the Aruban florin), while others use the currency of the core country and can easily be classified in the 'no separate legal tender' category (e.g., American Samoa which uses the US\$, Guernsey using the UK $\mathcal{f}_{\text {). }}$. Some affiliated territories participate jointly in monetary unions, with the legal tender being a distinct currency (e.g., the Eastern Caribbean dollar of the Organisation of Eastern Caribbean States). They can be easily classified outside the 'no legal tender category' following the IMF classification. On the other hand, some other affiliated territories participate in a monetary union because of their affiliation or integration to a core country that is the official member of the monetary union. This is the case for eight French overseas territories, the Azores, the Canary Islands and Madeira which have used the Euro since the entry of France, Spain and Portugal into the Eurozone, but these affiliated territories have no distinct seat on the ECB board. So, we consider that these territories enter in the category of 'no separate legal tender'.

The coding could be simply 1 when having its own currency and 0 when the territory belongs to the "no separate legal tender" category. We, however, allow for an intermediate category (with a score of 0.5 ) which groups territories that have their own national currency but have adopted a 'currency board arrangement' (IMF, 2018, p.7, defines a currency board arrangement as "a monetary arrangement based on an explicit legislative commitment to exchange domestic currency for a specified foreign currency at a fixed exchange rate, combined with restrictions on the issuing authority to ensure the fulfilment of its legal obligation"). The IMF classifies 'currency board arrangements', together with the cases of 'no separate legal tender' into the 'hard pegs' category. In these cases the end result is a surrender of the control of the national currency without having control of the anchor currency.

According to this coding, 40 territories are scored 1,11 are scored 0.5 , and 53 are scored 0. 


\section{Discussions of the results}

Figure 1 below presents the scores of the 104 small islands or coastal territories according to our composite index of formal sovereignty. Out of the 104 small territories in our sample, 43 are UN members (and so would have scored 1 - the other 61 would have scored 0 - in the binary classification). Detailed results for the individual territories are available in the Appendix.

It demonstrates that our index, with its intermediate scores, is able to reflect the continuous 'spectrum' between sovereignty and affiliation. Only 10 territories are scored 0: two non-self-governing overseas territories of Australia (Christmas Islands and Cocos Keeling Islands), one territory of Norway (Svalbard), the British Sovereign Base Areas of Akrotiri and Dhekelia, and the five French Overseas departements. The other 51 non-UN members show partial sovereignty.

Out of the $43 \mathrm{UN}$ members, only 24 are scored 1 (fully sovereign); the other 19 have full or partial surrender of power in specific dimensions.

The scores of non-UN members are between 0 and 0.92 and the scores of UN members are between 0.58 and 1 . These results show that the binary classification based on UN membership is at least significantly limited, if not mistaken, because according to our methodology and index some territories which are not UN members have a higher sovereignty score than some UN members. Besides Taiwan, which is a well-known case, four other non-UN members-Anguilla, Montserrat, Bermuda, and Gibraltar-have a higher level of sovereignty than some UN members, specifically Marshall Islands, Federated States of Micronesia, Monaco, and Tuvalu.

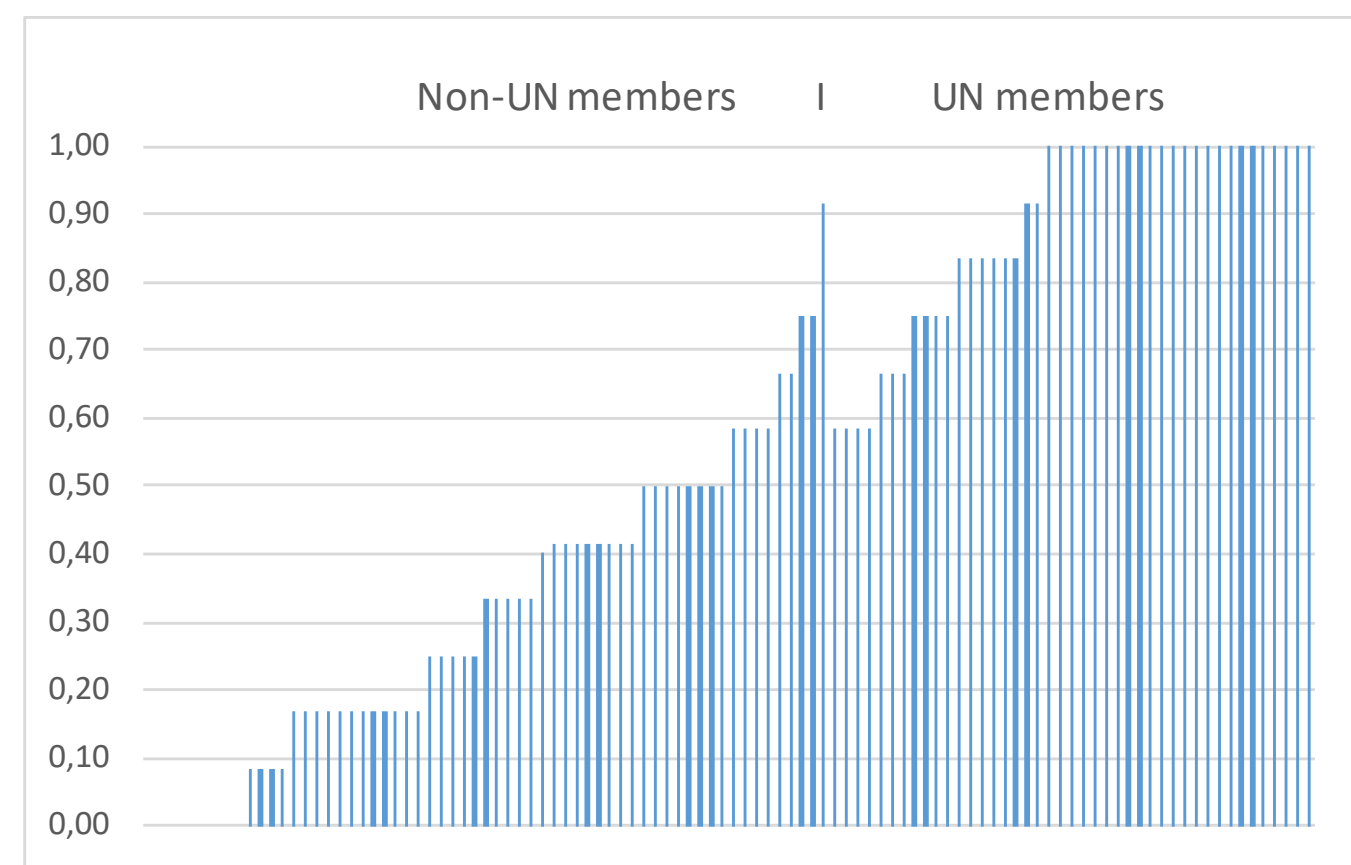

Figure 1: Index of formal sovereignty. Notes: 104 small islands and coastal territories. 61 non-UN members (on left) and 43 UN members (on right). Scores are between 0 (full dependency) and 1 (full sovereignty). 


\section{Conclusion}

Our composite index scores the degree of formal sovereignty for a large sample of small islands and coastal territories on a continuous scale, as an alternative to the binary classification of 'Sovereign vs Affiliated'. Our index, with its intermediate scores, is able to reflect the continuous 'spectrum' between sovereignty and affiliation. Covering 104 territories, this index can be used in large-scale comparative quantitative analyses. It can help to study the difference between de jure and de facto sovereignty.

It would also help to improve the tests of the impact of sovereignty on economic development. In regressions, while taking into account the other determinants of development, the use of a binary variable models a common and unique impact of being 'sovereign' (or acquiring sovereignty) versus being 'non-sovereign' (a one-off shift from 0 to 1). On the contrary, our index is continuous, from 0 to 1 in decimal point steps, and so allows the assessment of the impact of smaller differences in sovereignty, or of a gradual shift within the spectrum of sovereignty. Also, contrary to the binary variable, our proposed index allows the modelling and testing of non-linear impacts of sovereignty (which may have theoretical roots), of diminishing returns (i.e., a diminishing impact when passing from low levels to higher levels of sovereignty), of threshold effects (i.e., no further impact of progressing in sovereignty when a specific level is attained), and of inversed-U-shaped effect (i.e., a positive effect when progressing at low level of sovereignty but negative effect when progressing at a higher level).

The process of coding qualitative information to get quantitative scores and to aggregate them cannot be done with total objectivity and should be approached carefully. However, our coding process is simple and transparent, allowing for criticism, and future improvement. The geographical coverage could also be enhanced by participative work with other interested academics. A further step could be to build a historical series, probably by using a simplified version of the index, which would allow a description of the gradual changes in sovereignty.

\section{Acknowledgements}

This research was supported by the Agence Nationale de la Recherche of the French government through the program 'Investissements d'avenir' (ANR-10-LABX-14-01), through the IDGM+ initiative led by Ferdi (Fondation pour les études et recherches sur le développement international).

We thank the Editor and the reviewers for their comments on the previous versions of the paper. Specifically, the coding has significantly changed between preliminary versions and the current version. Initiation of this work benefited from the assistance of Yohan Queyla several years ago. All mistakes remain ours.

\section{References}

AOSIS (2019). Alliance of Small Island States. http://aosis.org/about/.

Armstrong H. W., \& Read, R. (2000). Comparing the economic performance of dependent territories and sovereign microstates. Economic Development and Cultural Change, 48(2), 285-306. 
Baldacchino, G. (2010). Island enclaves: Offshoring strategies, creative governance, and subnational island jurisdictions. Montreal: McGill-Queen's University Press. https://doi.org/10.1177/1474474013478369

Baldacchino G., \& Hepburn E. (2012). A different appetite for sovereignty? Independence movements in subnational island jurisdictions. Commonwealth and Comparative Politics, 50(4), 555-568. https://doi.org/10.1080/14662043.2012.729735

Bertram, G. (2004). On the convergence of small island economies with their metropolitan patrons. World Development, 32(2), 343-364. https://doi.org/10.1016/j.worlddev.2003.08.004

Bertram, G. (2015). Is independence good or bad for development in small island economies? A long-run analysis. Région et Développement, 42, 31-54.

Bonilla, Y., \& Hantel, M. (2016) Visualizing sovereignty: Cartographic queries for the Digital Age. SX: Archipelagos, 1, 1-19.

CIA (2019). World Factbook. Central Intelligence Agency.

Cobham A., Janský P., \& Meinzer, M. (2015). The financial secrecy index: Shedding new light on the geography of secrecy. Economic Geography, 91(3), 281-303. https://doi.org/10.1111/ecge.12094

Cukierman, A. (2009). Central bank independence and monetary policy-making institutions: Past, present and future. In H. Herrmann, D. Mayes, \& G. E. Wood (eds..) Designing Central Banks (pp. 82-120). Abingdon: Routledge.

Dunn, L. (2011). The impact of political dependence on small island jurisdictions. World Development, 39(12), 2132-2146. https://doi.org/10.1016/j.worlddev.2011.04.002

Feyrer, J., \& Sacerdote, B. (2009). Colonialism and modern income: Islands as natural experiments. Review of Economics and Statistics, 91(2), 245-262. https://doi.org/10.1162/rest.91.2.245

Gagnon, A. G., \& Keating, M. (2012). Political autonomy and divided societies: Imagining democratic alternatives in complex settings. Basingstoke: Palgrave MacMillan.

Gianviti, F. (2004). Current legal aspects of monetary sovereignty. In Seminar on current developments in monetary and financial law. Washington, DC: IMF.

Grydehøj, A. (2016a). Toward subnational democracies of scale: Tensions between democratic legitimacy, legality, and effective governance. Geopolitics, 21(1), 22-42. https://doi.org/10.1080/14650045.2015.1114918

Grydehøj, A. (2016b). Navigating the binaries of island independence and dependence in Greenland: Decolonisation, political culture, and strategic services. Political Geography, 55, 102-112. https://doi.org/10.1016/j.polgeo.2016.09.001

Hooghe, L., Marks, G. N., \& Schakel, A. H. (2010). The rise of regional authority: A comparative study of 42 democracies. Abingdon: Routledge.

Hooghe, L., Marks, G., Schakel, A. H., Osterkatz, S. C., Niedzwiecki, S., \& Shair-Rosenfield, S. (2016). Measuring regional authority: A postfunctionalist theory of governance. Oxford: Oxford University Press. https://doi.org/10.1093/acprof:oso/9780198728870.001.0001

International Monetary Fund (2018). Annual report on exchange arrangements and exchange restrictions. Washington DC: IMF. https://doi.org/10.5089/9781451942606.012

Karlsson, A. (2009). Sub-national island jurisdictions as configurations of jurisdictional powers and economic capacity: Nordic experiences from Åland, Faroes and Greenland. Island Studies Journal, 4(2), 139-162. 
Ladner, A., Keuffer N., \& Baldersheim H. (2015), Local autonomy index for European countries (1990-2014). Release 1.0. Brussels: European Commission.

Ladner, A., Keuffer N., \& Baldersheim H. (2016). Measuring local autonomy in 39 countries (1990-2014), Regional \& Federal Studies, 26(3), 321-357. https://doi.org/10.1080/13597566.2016.1214911

Madiès, T., Rota-Grasiozi G., Tranchant J.P., \& Trépier C. (2018). The economics of secession: A review of legal, theoretical, and empirical aspects. Swiss Journal of Economics and Statistics, 154(1), 19. https://doi.org/10.1186/s41937-017-0015-6

McElroy, J.L., \& Parry C.E. (2012). The long-term propensity for political affiliation in island microstates. Commonwealth \& Comparative Politics, 50(4), 403-421. https://doi.org/10.1080/14662043.2012.729727

McElroy, J.L., \& Pearce, K.B. (2006). The advantages of political affiliation: Dependent and independent small-island profiles. The Round Table, 95(386), 529-539. https://doi.org/10.1080/00358530600931285

McElroy, J.L., \& Sanborn, K. (2005). The propensity for dependence in small Caribbean and Pacific islands. Bank of Valletta Review, 31(1), 1-16.

Mrgudovic, N. (2012). Evolving approaches to sovereignty in the French Pacific. Commonwealth E Comparative Politics, 50(4), 456-473. https://doi.org/10.1080/14662043.2012.729730

Overton, J., Prinsen, G., Murray, W. E., \& Wrighton N. (2012). Reversing the tide of aid: Investigating development policy sovereignty in the Pacific. Le Journal de la Société des Océanistes, 135, n.p. https://doi.org/10.4000/jso.6713

Pöllath, M. (2018). Revisiting island decolonization: The pursuit of self-government in Pacific island polities under US hegemony. Island Studies Journal, 13(1), 235-250. https://doi.org/10.24043/isj.46

Prinsen, G., Lafoy Y., \& Migozzi J. (2017). Showcasing the sovereignty of non-self-governing islands: New Caledonia. Asia Pacific Viewpoint, 58(3), 331-346. https://doi.org/10.1111/apv.12151

Rezvani, D. A. (2014). Surpassing the sovereign state: The wealth, self-rule, and security advantages of partially independent territories. Oxford: Oxford University Press. https://doi.org/10.1093/acprof:oso/9780199688494.001.0001

Shaw, M. N. (2017). International Law. Eighth Edition. Cambridge: Cambridge University Press. Stuart, K. (2008). A global listing of sub-national island jurisdictions. In G. Baldacchino and K. Stuart (Eds.) Pulling strings: Policy insights for Prince Edward Island from other sub-national island jurisdictions (pp. 173-185). Charlottetown: Island Studies Press. https://doi.org/10.1080/00358530600929735

Suksi, M. (2012). Sub-state governance through territorial autonomy: On the relationship between autonomy and federalism. In A. G. Gagnon \& M. Keating (eds.). Political autonomy and divided societies: Imagining democratic alternatives in complex settings. Basingstoke: Palgrave MacMillan. https://doi.org/10.1057/9780230365322 5

United Nations (n.d.). Funds, programmes, specialized agencies and others. http://www.un.org/en/sections/about-un/funds-programmes-specialized-agenciesand-others/index.html. 
van Zyl Smit, J. (2015). The appointment, tenure and removal of judges under Commonwealth principles: A compendium and analysis of best practices (report of research undertaken by Bingham Centre for the Rule of Law). London: Commonwealth Secretariat. https://doi.org/10.1080/03050718.2015.1093767

Veenendaal, W. (2019). Islands of democracy. Area. Epub ahead of print. https://doi.org/10.1111/area.12462.

Verstraeten, S. P., van Oers, H. A., \& Mackenbach, J. P. (2016). Decolonization and life expectancy in the Caribbean. Social Science \& Medicine, 170, 87-96. https://doi.org/10.1016/j.socscimed.2016.08.048

Watts, R.L. (2009). Island jurisdictions in comparative constitutional perspective. In G. Baldacchino and D. Milne (Eds.) The case for non-sovereignty: Lessons from sub-national island jurisdictions (pp. 21-39). London: Routledge.

Zimmermann, C.D. (2013). The concept of monetary sovereignty revisited. European Journal of International Law, 24(3), 797-818. 
Appendix: Index of formal sovereignty for 104 small islands and coastal territories

\begin{tabular}{|c|c|c|c|c|c|c|c|c|}
\hline & UN mem. & Composite & Diplom. & Exec. & Judic. & Legis. & Def. & Monet. \\
\hline Akrotiri & 0 & 0.00 & 0 & 0 & 0 & 0 & 0 & 0 \\
\hline Aland Islands & 0 & 0.25 & 0 & 1 & 0 & 0.5 & 0 & 0 \\
\hline $\begin{array}{l}\text { American } \\
\text { Samoa }\end{array}$ & 0 & 0.42 & 0.5 & 1 & 0.5 & 0.5 & 0 & 0 \\
\hline Anguilla & 0 & 0.67 & 0.5 & 1 & 1 & 1 & 0 & 0.5 \\
\hline $\begin{array}{l}\text { Antigua \& } \\
\text { Barbuda }\end{array}$ & 1 & 0.92 & 1 & 1 & 1 & 1 & 1 & 0.5 \\
\hline Aruba & 0 & 0.58 & 0.5 & 1 & 0.5 & 0.5 & 0 & 1 \\
\hline Azores & 0 & 0.17 & 0 & 0.5 & 0 & 0.5 & 0 & 0 \\
\hline Bahamas & 1 & 1.00 & 1 & 1 & 1 & 1 & 1 & 1 \\
\hline Bahrain & 1 & 1.00 & 1 & 1 & 1 & 1 & 1 & 1 \\
\hline Barbados & 1 & 1.00 & 1 & 1 & 1 & 1 & 1 & 1 \\
\hline Belize & 1 & 1.00 & 1 & 1 & 1 & 1 & 1 & 1 \\
\hline Bermuda & 0 & 0.75 & 0.5 & 1 & 0.5 & 0.5 & 1 & 1 \\
\hline Bonaire & 0 & 0.17 & 0.5 & 0 & 0.5 & 0 & 0 & 0 \\
\hline Bougainville & 0 & 0.50 & 0.5 & 1 & 1 & 0.5 & 0 & 0 \\
\hline $\begin{array}{l}\text { British Indian } \\
\text { Ocean Territory }\end{array}$ & 0 & 0.08 & 0.5 & 0 & 0 & 0 & 0 & 0 \\
\hline $\begin{array}{l}\text { British Virgin } \\
\text { Islands }\end{array}$ & 0 & 0.50 & 0.5 & 1 & 1 & 0.5 & 0 & 0 \\
\hline Cabo Verde & 1 & 1.00 & 1 & 1 & 1 & 1 & 1 & 1 \\
\hline Canary Islands & 0 & 0.08 & 0 & 0.5 & 0 & 0 & 0 & 0 \\
\hline Cayman Islands & 0 & 0.58 & 0.5 & 1 & 0.5 & 0.5 & 0 & 1 \\
\hline Christmas Island & 0 & 0.00 & 0 & 0 & 0 & 0 & 0 & 0 \\
\hline $\begin{array}{l}\text { Cocos (Keeling) } \\
\text { Islands }\end{array}$ & 0 & 0.00 & 0 & 0 & 0 & 0 & 0 & 0 \\
\hline Comoros & 1 & 1.00 & 1 & 1 & 1 & 1 & 1 & 1 \\
\hline Cook Islands & 0 & 0.42 & 0.5 & 1 & 0.5 & 0.5 & 0 & 0 \\
\hline Corsica & 0 & 0.08 & 0 & 0.5 & 0 & 0 & 0 & 0 \\
\hline Cuba & 1 & 1.00 & 1 & 1 & 1 & 1 & 1 & 1 \\
\hline Curaçao & 0 & 0.58 & 0.5 & 1 & 0.5 & 0.5 & 0 & 1 \\
\hline Cyprus & 1 & 1.00 & 1 & 1 & 1 & 1 & 1 & 1 \\
\hline Dhekelia & 0 & 0.00 & 0 & 0 & 0 & 0 & 0 & 0 \\
\hline Dominica & 1 & 0.75 & 1 & 1 & 1 & 1 & 0 & 0.5 \\
\hline $\begin{array}{l}\text { Dominican } \\
\text { Republic }\end{array}$ & 1 & 1.00 & 1 & 1 & 1 & 1 & 1 & 1 \\
\hline $\begin{array}{l}\text { Falkland Islands } \\
\text { (Islas Malvinas) }\end{array}$ & 0 & 0.33 & 0.5 & 0 & 0 & 0.5 & 0 & 1 \\
\hline Faroe Islands & 0 & 0.42 & 0.5 & 1 & 0 & 0.5 & 0 & 0.5 \\
\hline Fiji & 1 & 1.00 & 1 & 1 & 1 & 1 & 1 & 1 \\
\hline French Guiana & 0 & 0.00 & 0 & 0 & 0 & 0 & 0 & 0 \\
\hline $\begin{array}{l}\text { French } \\
\text { Polynesia }\end{array}$ & 0 & 0.42 & 0.5 & 0.5 & 0 & 0.5 & 0 & 1 \\
\hline Gibraltar & 0 & 0.75 & 0.5 & 1 & 0.5 & 0.5 & 1 & 1 \\
\hline Greenland & 0 & 0.42 & 0.5 & 1 & 0.5 & 0.5 & 0 & 0 \\
\hline Grenada & 1 & 0.75 & 1 & 1 & 1 & 1 & 0 & 0.5 \\
\hline Guadeloupe & 0 & 0.00 & 0 & 0 & 0 & 0 & 0 & 0 \\
\hline Guam & 0 & 0.50 & 0.5 & 1 & 1 & 0.5 & 0 & 0 \\
\hline Guernsey & 0 & 0.33 & 0.5 & 1 & 0 & 0.5 & 0 & 0 \\
\hline Guinea-Bissau & 1 & 1.00 & 1 & 1 & 1 & 1 & 1 & 1 \\
\hline Guyana & 1 & 1.00 & 1 & 1 & 1 & 1 & 1 & 1 \\
\hline Haiti & 1 & 1.00 & 1 & 1 & 1 & 1 & 1 & 1 \\
\hline Hawaii & 0 & 0.50 & 0 & 1 & 1 & 1 & 0 & 0 \\
\hline
\end{tabular}


François Alberti \& Michaël Goujon

\begin{tabular}{|c|c|c|c|c|c|c|c|c|}
\hline & UN mem. & Composite & Diplom. & Exec. & Judic. & Legis. & Def. & Monet. \\
\hline Hong Kong & 0 & 0.50 & 0.5 & 0.5 & 1 & 0.5 & 0 & 0.5 \\
\hline Iceland & 1 & 0.83 & 1 & 1 & 1 & 1 & 0 & 1 \\
\hline Isle of Man & 0 & 0.33 & 0.5 & 1 & 0 & 0.5 & 0 & 0 \\
\hline Jamaica & 1 & 1.00 & 1 & 1 & 1 & 1 & 1 & 1 \\
\hline Jersey & 0 & 0.25 & 0 & 1 & 0 & 0.5 & 0 & 0 \\
\hline Kiribati & 1 & 0.67 & 1 & 1 & 1 & 1 & 0 & 0 \\
\hline Macau & 0 & 0.50 & 0.5 & 0.5 & 1 & 0.5 & 0 & 0.5 \\
\hline Madeira & 0 & 0.25 & 0.5 & 0.5 & 0 & 0.5 & 0 & 0 \\
\hline Maldives & 1 & 1.00 & 1 & 1 & 1 & 1 & 1 & 1 \\
\hline Malta & 1 & 1.00 & 1 & 1 & 1 & 1 & 1 & 1 \\
\hline Marshall Islands & 1 & 0.58 & 1 & 1 & 1 & 0.5 & 0 & 0 \\
\hline Martinique & 0 & 0.00 & 0 & 0 & 0 & 0 & 0 & 0 \\
\hline Mauritius & 1 & 0.83 & 1 & 1 & 1 & 1 & 0 & 1 \\
\hline Mayotte & 0 & 0.00 & 0 & 0 & 0 & 0 & 0 & 0 \\
\hline $\begin{array}{l}\text { Micronesia, Fed } \\
\text { States }\end{array}$ & 1 & 0.58 & 1 & 1 & 1 & 0.5 & 0 & 0 \\
\hline Monaco & 1 & 0.58 & 1 & 1 & 1 & 0.5 & 0 & 0 \\
\hline Montserrat & 0 & 0.67 & 0.5 & 1 & 1 & 1 & 0 & 0.5 \\
\hline Nauru & 1 & 0.67 & 1 & 1 & 1 & 1 & 0 & 0 \\
\hline New Caledonia & 0 & 0.42 & 0.5 & 0.5 & 0 & 0.5 & 0 & 1 \\
\hline Niue & 0 & 0.42 & 0.5 & 1 & 0.5 & 0.5 & 0 & 0 \\
\hline Norfolk Island & 0 & 0.17 & 0.5 & 0 & 0 & 0.5 & 0 & 0 \\
\hline $\begin{array}{l}\text { Northern } \\
\text { Mariana Isl }\end{array}$ & 0 & 0.33 & 0.5 & 1 & 0 & 0.5 & 0 & 0 \\
\hline Nunavut & 0 & 0.25 & 0 & 1 & 0 & 0.5 & 0 & 0 \\
\hline Palau & 1 & 0.67 & 1 & 1 & 1 & 1 & 0 & 0 \\
\hline $\begin{array}{l}\text { Papua New } \\
\text { Guinea }\end{array}$ & 1 & 1.00 & 1 & 1 & 1 & 1 & 1 & 1 \\
\hline Pitcairn Islands & 0 & 0.25 & 0.5 & 0.5 & 0 & 0.5 & 0 & 0 \\
\hline Puerto Rico & 0 & 0.50 & 0.5 & 1 & 1 & 0.5 & 0 & 0 \\
\hline Réunion & 0 & 0.00 & 0 & 0 & 0 & 0 & 0 & 0 \\
\hline Saba & 0 & 0.17 & 0.5 & 0 & 0.5 & 0 & 0 & 0 \\
\hline $\begin{array}{l}\text { Saint } \\
\text { Barthélémy }\end{array}$ & 0 & 0.17 & 0.5 & 0.5 & 0 & 0 & 0 & 0 \\
\hline $\begin{array}{l}\text { St Helena, } \\
\text { Ascension, and } \\
\text { Tristan da } \\
\text { Cunha }\end{array}$ & 0 & 0.17 & 0.5 & 0 & 0 & 0.5 & 0 & 0 \\
\hline $\begin{array}{l}\text { Saint Kitts and } \\
\text { Nevis }\end{array}$ & 1 & 0.92 & 1 & 1 & 1 & 1 & 1 & 0.5 \\
\hline Saint Lucia & 1 & 0.75 & 1 & 1 & 1 & 1 & 0 & 0.5 \\
\hline Saint Martin & 0 & 0.17 & 0.5 & 0.5 & 0 & 0 & 0 & 0 \\
\hline $\begin{array}{l}\text { SaintPierre } \\
\text { \&Miquelon }\end{array}$ & 0 & 0.17 & 0.5 & 0.5 & 0 & 0 & 0 & 0 \\
\hline $\begin{array}{l}\text { Saint Vincent \& } \\
\text { the Grenadines }\end{array}$ & 1 & 0.75 & 1 & 1 & 1 & 1 & 0 & 0.5 \\
\hline Samoa & 1 & 0.83 & 1 & 1 & 1 & 1 & 0 & 1 \\
\hline $\begin{array}{l}\text { Sao Tome and } \\
\text { Principe }\end{array}$ & 1 & 1.00 & 1 & 1 & 1 & 1 & 1 & 1 \\
\hline Sardinia & 0 & 0.17 & 0 & 0.5 & 0 & 0.5 & 0 & 0 \\
\hline Seychelles & 1 & 1.00 & 1 & 1 & 1 & 1 & 1 & 1 \\
\hline Sicily & 0 & 0.17 & 0 & 0.5 & 0 & 0.5 & 0 & 0 \\
\hline Singapore & 1 & 1.00 & 1 & 1 & 1 & 1 & 1 & 1 \\
\hline Sint Eustatius & 0 & 0.17 & 0.5 & 0 & 0.5 & 0 & 0 & 0 \\
\hline Sint Maarten & 0 & 0.58 & 0.5 & 1 & 0.5 & 0.5 & 0 & 1 \\
\hline
\end{tabular}


Island Studies Journal, 15(1), 2020, 3-24

\begin{tabular}{|l|c|c|c|c|c|c|c|c|}
\hline & UN mem. & Composite & Diplom. & Exec. & Judic. & Legis. & Def. & Monet. \\
\hline Solomon Islands & 1 & 0.83 & 1 & 1 & 1 & 1 & 0 & 1 \\
\hline Sri Lanka & 1 & 1.00 & 1 & 1 & 1 & 1 & 1 & 1 \\
\hline Suriname & 1 & 1.00 & 1 & 1 & 1 & 1 & 1 & 1 \\
\hline Svalbard & 0 & 0.00 & 0 & 0 & 0 & 0 & 0 & 0 \\
\hline Taiwan & 0 & 0.92 & 0.5 & 1 & 1 & 1 & 1 & 1 \\
\hline Timor-Leste & 1 & 0.83 & 1 & 1 & 1 & 1 & 1 & 0 \\
\hline Tokelau & 0 & 0.42 & 0.5 & 1 & 0 & 1 & 0 & 0 \\
\hline Tonga & 1 & 1.00 & 1 & 1 & 1 & 1 & 1 & 1 \\
\hline $\begin{array}{l}\text { Trinidad and } \\
\text { Tobago }\end{array}$ & 1 & 1.00 & 1 & 1 & 1 & 1 & 1 & 1 \\
\hline $\begin{array}{l}\text { Turks and } \\
\text { Caicos Islands }\end{array}$ & 0 & 0.42 & 0.5 & 1 & 0.5 & 0.5 & 0 & 0 \\
\hline Tuvalu & 1 & 0.58 & 1 & 1 & 0.5 & 1 & 0 & 0 \\
\hline $\begin{array}{l}\text { United States } \\
\text { Virgin Islands }\end{array}$ & 0 & 0.50 & 0.5 & 1 & 1 & 0.5 & 0 & 0 \\
\hline Vanuatu & 1 & 0.83 & 1 & 1 & 1 & 1 & 0 & 1 \\
\hline $\begin{array}{l}\text { Wallis and } \\
\text { Futuna }\end{array}$ & 0 & 0.33 & 0.5 & 0.5 & 0 & 0 & 0 & 1 \\
\hline Zanzibar & 0 & 0.17 & 0 & 0.5 & 0 & 0.5 & 0 & 0 \\
\hline
\end{tabular}


François Alberti E Michaël Goujon 